\title{
Serum levels of vascular endothelial growth factor and basic fibroblast growth factor in children with brain tumors
}

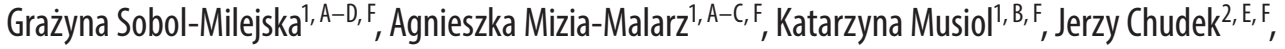 \\ Maria Bożentowicz-Wikarek ${ }^{2, B}$, Halina Wos ${ }^{1}$, , Marek Mandera ${ }^{3, E}$ \\ 1 Department of Pediatric Oncology, Hematology and Chemotherapy, Upper Silesia Children's Care Health Centre, Medical University of Silesia, Katowice, Poland \\ 2 Department of Pathophysiology, Medical University of Silesia, Katowice, Poland \\ ${ }^{3}$ Department of Neurosurgery, Upper Silesia Children's Care Health Centre, Medical University of Silesia, Katowice, Poland \\ A - research concept and design; $B$ - collection and/or assembly of data; $C$ - data analysis and interpretation; \\ $D$ - writing the article; $E$ - critical revision of the article; $F$ - final approval of article
}

Address for correspondence

Grażyna Sobol-Milejka

E-mail: gsobol@02.pl

Funding sources

None declared

Conflict of interest

None declared

Received on August 16, 2015

Revised on November 10, 2015

Accepted on March 22, 2016

\begin{abstract}
Background. Angiogenesis is the process of new vessel formation originating from the existing vascular network. It plays an important role in the growth and spread of malignancies, including brain tumors. The process of angiogenesis is characterized by increased expression of vascular endothelial growth factor (VEGF) and basic fibroblast growth factor (bFGF), and by the release of their soluble forms into circulation.

Objectives. The aim of the study was to evaluate serum levels of VEGF and bFGF in children with malignant and benign brain tumors.

Material and methods. The study group (group N) included 106 children diagnosed with brain tumors. The children in group $N$ were classified according to tumor pathology into 3 subgroups: $N 1(n=63)$ : patients with malignant tumors, excluding anaplastic astrocytoma (AA) and glioblastoma multiforme $(G B M) ; N 2(n=25)$ : patients with benign tumors; and N3 $(n=18)$ : patients with high grade gliomas (AA and GBM). VEGF and bFGF were determined by ELISA in blood samples before the initiation of chemotherapy. VEGF and bFGF levels were compared within the subgroups in relation to tumor grading and the extent of surgery.
\end{abstract}

Results. The median VEGF in patients with brain tumors was significantly higher than in the control group. The median levels of VEGF and bFGF in subgroup N1 were significantly higher than in the control group. The differences in VEGF and bFGF concentrations between the subgroups in relation to the extent of tumor resection were not significant.

Conclusions. Significantly higher plasma VEGF levels in children with brain neoplasms may reflect enhanced angiogenesis in the tumors.

Key words: children, vascular endothelial growth factor, brain tumor, basic fibroblast growth factor

DOI

$10.17219 /$ acem $/ 62320$

Copyright

Copyright by Author(s)

This is an article distributed under the terms of the

Creative Commons Attribution Non-Commercial License

(http://creativecommons.org/licenses/by-nc-nd/4.0/) 
Angiogenesis is the process of new vessel formation originating from the existing vascular network. It plays an important role in the growth and spread of malignant tumors. Neovascularization is stimulated by environmental factors and mediated by oncogenes and cytokines. Hypoxia is the strongest local environmental factor that induces angiogenesis. It activates the expression of vascular endothelial growth factor (VEGF), thus stimulating tumor cells to produce and release cytokines, which trigger neovascularization. ${ }^{1-3}$ The activation of some oncogenes, such as KRAS, HRAS, SRC and bcl-2, is responsible not only for malignant transformation, but also for VEGF transcription, which promotes angiogenesis. ${ }^{4}$ VEGF and basic fibroblast growth factor (bFGF) are crucial for angiogenesis. ${ }^{5,6}$ Angiogenesis increased by tumors appears to be an important risk factor for the progression, recurrence and metastases of different tumors, including brain tumors. ${ }^{1-3,7,8}$ Brain tumors constitute $35-40 \%$ of all solid tumors, and approximately $22-28 \%$ of all cancers in children. ${ }^{9}$ Despite significant progress in the treatment of brain tumors, which currently includes neurosurgery, chemotherapy and radiotherapy, the outcomes are still unsatisfactory, and therefore, research for new therapies against brain tumor continues. ${ }^{10}$ Recently, numerous researchers have focused on angiogenesis in brain tumors and the use of pro-angiogenic factor inhibitors in treating them, in children as well as adults. ${ }^{9,11-19}$ The number of reports on angiogenesis in brain tumors in children is very limited, which indicates a need to address the topic. The aim of the present study was to evaluate serum levels of VEGF and bFGF in children diagnosed with malignant and benign brain tumors.

\section{Material and methods}

The study included 106 children (61 boys - 57.5\%; and 45 girls $-42.5 \%$ ), aged from 7 months to 19 years (mean 8.9 years) with brain tumors (group $\mathrm{N}$ ). The children in group $\mathrm{N}$ were divided according to pathological diagnosis into the following three subgroups:

- subgroup N1 ( $n=63)$ : patients with malignant tumors, excluding anaplastic astrocytomas (AA) and glioblastomas multiforme (GBM). This subgroup included medulloblastomas $(\mathrm{n}=30)$, anaplastic ependymomas $(\mathrm{n}=11)$, germinomas $(n=5)$, pineoblastomas $(n=2)$, choroid plexus carcinomas $(n=2)$ and morphologically unidentified brain stem tumors (probably malignant gliomas, based on MRIs) ( $\mathrm{n}=13)$;

- subgroup N2 ( $\mathrm{n}=25)$ : patients with benign tumors (pilocytic astrocytomas);

- subgroup N3 ( $\mathrm{n}=18)$ : patients with high grade gliomas (AA and GBM).

Additionally, based on the extent of surgical resection, the following subgroups were identified: subgroup PR: partial resection $(n=62)$; subgroup TR: total resection ( $\mathrm{n}=18$ ); subgroup STR: subtotal resection ( $\mathrm{n}=7$ ); subgroup B: biopsy $(n=6)$; and subgroup NV: not verified ( $\mathrm{n}=13)$.

All the patients were treated according to the Uniform Protocol for the Treatment of Brain Tumors in Children developed by the Polish Pediatric Neuro-Oncology Group. ${ }^{9}$ The control group (group C) consisted of 34 children aged from 2 to 17 years (mean age: 8.5 years) diagnosed with functional gastrointestinal disorder.

Serum levels of proangiogenic cytokines, VEGF and bFGF were determined in the study group before chemotherapy. All serum levels were determined using immunoenzymatic assay (ELISA) kits (R\&D Systems, Minneapolis, USA).

The statistical analysis of the data obtained was performed using STATISTICA software, v. 10 (SatSoft Inc., Tulsa, USA). The statistical analysis included the MannWhitney U-test and Kruskal-Wallis test, followed by the Dunn post-hoc test. A p-value $<0.05$ was considered statistically significant.

The study protocol was approved by the Local Bioethics Committee. Each patient's parents or carers signed informed consent for participation in the study. Consent was also obtained directly from older children.

\section{Results}

The serum VEGF and bFGF levels in the entire study group of patients with malignant and benign brain tumors (group N) and the subgroups (N1, N2 and N3) as compared to the control group (group C) were analyzed.

The median serum VEGF level was $260.9 \mathrm{pg} / \mathrm{mL}$ (range: $17.8-2000 \mathrm{pg} / \mathrm{mL}$ ) in group $\mathrm{N}$ and $194.1 \mathrm{pg} / \mathrm{mL}$ (range: 31.4-448.1 pg/mL) in group C. The difference was statistically significant $(\mathrm{p}=0.05$; Table 1$)$.

The median bFGF levels in group $\mathrm{N}$ and group $\mathrm{C}$ were similar: $7.64 \mathrm{pg} / \mathrm{mL}$ (range: $0.05-79.23 \mathrm{pg} / \mathrm{mL}$ ) and 7.64 pg/mL (range: $2.7-48.7$ ) respectively (Table 1 ).

The analysis of VEGF and bFGF within the subgroups according to tumor grading revealed statistically significant differences between the control group and subgroup $\mathrm{N} 1$ ( $\mathrm{p}=0.03$ and $\mathrm{p}=0.04$, respectively; Table 1$)$. The difference in VEGF levels between subgroups N2 and N3 was also statistically significant ( $\mathrm{p}=0.005$; Table 1 ).

There were no statistically significant differences in VEGF and bFGF concentrations between the subgroups according to tumor resection (Table 2).

\section{Discussion}

Gliomas are the most common brain tumors in children, constituting over $50 \%$ of all tumor cases. These can be further divided into low grade gliomas (LGG), which 
Table 1. Serum vascular endothelial growth factor (VEGF) and basic fibroblast growth factor (bFGF) levels in children with brain tumors and in the control group. Subgroup N1: patients with malignant tumors, excluding anaplastic astrocytomas (AA) and glioblastomas multiforme (GBM); N2: patients with benign tumors; and N3: patients with high grade gliomas (AA and GBM). The data are presented as median values with 25-75 percentiles in parentheses

\begin{tabular}{|c|c|c|}
\hline Study groups & VEGF (pg/mL) & bFGF (pg/mL) \\
\hline $\begin{array}{l}\text { Group N ( } \mathrm{n}=106) \\
\text { (children with brain tumors) }\end{array}$ & $\begin{array}{c}260.9^{*} \\
(17.8-2000.0)\end{array}$ & $\begin{array}{c}7.64 \\
(0.05-79.2)\end{array}$ \\
\hline $\begin{array}{l}\text { Subgroup N1 ( } \mathrm{n}=63 \text { ) } \\
\text { (patients with malignant } \\
\text { tumors, excluding anaplastic } \\
\text { astrocytomas (AA) and } \\
\text { glioblastomas multiforme) }\end{array}$ & $\begin{array}{c}234.9^{*} \\
(28.3-2000.0)\end{array}$ & $\begin{array}{c}7.53^{*} \\
(0.05-79.2)\end{array}$ \\
\hline $\begin{array}{l}\text { Subgroup N2 }(n=25) \\
\text { (patients with benign tumors) }\end{array}$ & $\begin{array}{c}193.3^{* *} \\
(40.1-509.4)\end{array}$ & $\begin{array}{c}8.05^{* *} \\
(0.6-25.2)\end{array}$ \\
\hline $\begin{array}{l}\text { Subgroup N3 }(n=18) \\
\text { (patients with high grade } \\
\text { gliomas (AA and GBM) }\end{array}$ & $\begin{array}{c}179.0^{* *} \\
(17.8-453.3)\end{array}$ & $\begin{array}{c}5.92^{* *} \\
(0.3-21.4)\end{array}$ \\
\hline Control group $(n=34)$ & $\begin{array}{c}224.1 \\
(31.4-448.1)\end{array}$ & $\begin{array}{c}7.64 \\
(2.1-19.5)\end{array}$ \\
\hline
\end{tabular}

${ }^{*} p<0.05$ vs the control group; ${ }^{* *} p<0.05$ N2 vs N3.

include pilocytic astrocytomas (WHO grade I) or diffuse astrocytomas (WHO grade II), and high grade gliomas (HGG), which include anaplastic astrocytomas (WHO Grade III) and glioblastomas multiforme (WHO Grade IV). The 5-year survival rates are 80-90\% in LGG, 20-40\% in anaplastic astrocytoma and $5-15 \%$ in glioblastoma. ${ }^{10,20}$ Diffused brain stem gliomas are associated with the worst prognosis. The total survival in these cases is 9 months a truly poor treatment outcome that has remained unchanged for many decades. ${ }^{9,21,22}$
Among all types of cancer in children, brain tumors are associated with the worst prognosis and constitute the most common cause of disease-related mortality in children. ${ }^{9}$ Contrary to the authors' assumptions, the study results did not reveal higher serum levels of VEGF and bFGF in high grade gliomas (WHO III and WHO IV). However, this can potentially be attributed to the low number of patients in the HGG subgroup. Furthermore, the serum levels of the parameters analyzed were higher in the malignant tumor subgroup than in the benign tumor subgroup; the difference, however, was not statistically significant. Additionally, higher pro-angiogenic protein levels were observed in the entire study group as compared to the control group, but the difference was statistically significant only for VEGF. It is hard to relate these findings to the published data, as the rare publications discussing angiogenesis in brain tumors in children are mostly focused on antiangiogenic cancer therapy in relation to the use of the same agents in adult patients. Therefore, the discussion presented herein aims to explain the importance of investigating the significance of the observed elevated VEGF and bFGF levels.

Table 2. Serum vascular endothelial growth factor (VEGF) and basic fibroblast growth factor (bFGF) levels and the extent of surgery

\begin{tabular}{|c|c|c|c|c|c|c|}
\hline $\begin{array}{c}\text { Proangiogenic } \\
\text { cytokines }\end{array}$ & Type of resection & Mean & SD & Median & Minimum & Maximum \\
\hline \multirow{5}{*}{$\begin{array}{l}\text { VEGF } \\
\mathrm{pg} / \mathrm{mL}\end{array}$} & total resection & 286.73 & 266.40 & 220.65 & 34.90 & 796.80 \\
\hline & partial resection & 192.88 & 288.87 & 128.80 & 14.60 & 2000.00 \\
\hline & biopsy & 215.85 & 90.82 & 183.95 & 150.50 & 345.00 \\
\hline & not verified & 209.91 & 134.75 & 185.45 & 28.30 & 424.20 \\
\hline & subtotal resection & 427.03 & 506.70 & 121.40 & 82.40 & 1200.00 \\
\hline \multirow{4}{*}{$\begin{array}{l}\mathrm{FGF} \\
\mathrm{pg} / \mathrm{mL}\end{array}$} & total resection & 11.08 & 6.09 & 9.57 & 2.88 & 23.18 \\
\hline & biopsy & 5.34 & 3.45 & 4.74 & 2.15 & 9.73 \\
\hline & not verified & 5.96 & 4.98 & 5.43 & 0.27 & 13.85 \\
\hline & subtotal resection & 11.70 & 8.81 & 12.54 & 1.30 & 25.51 \\
\hline
\end{tabular}

${ }^{*} p<0.05$ vs the control group; ${ }^{* *} p<0.05$ N2 vs N3. 
The vascular network density in WHO II gliomas resembles that of healthy cerebral tissue. It increases significantly in WHO III gliomas (AA) to achieve peak value in GBM (WHO IV). Many researchers have reported a negative correlation between the vascular network density in tumor biopsy specimens and patient survival. ${ }^{23,24}$ In order to improve treatment outcomes in malignancies associated with the poorest prognoses, it is essential to implement new therapeutic approaches. This has led to researchers' interest in the phenomenon of angiogenesis in brain tumors, as anti-angiogenic treatment has become a hope of improving the prognosis in CNS tumors. ${ }^{4,8-21,23-29}$ The main source of interest in tumor angiogenesis was the hypothesis presented by Judah Folkman, who assumed that since tumor growth is blood supply-dependent, blocking angiogenesis may be a strategy to inhibit tumor growth. ${ }^{30}$

VEGF is the strongest factor triggering normal and pathological angiogenesis and stimulating cancer cells to proliferate. It is produced by endothelial cells, myocytes, macrophages, mastocytes, lymphocytes (CD4 cells), plasmocytes and tumor cells, whereas leukocytes and blood platelets are responsible for its transportation. The second best known factor stimulating normal and abnormal angiogenesis is bFGF, which is produced by fibroblasts, macrophages and tumor cells, while leukocytes and blood platelets are responsible for its transportation. 3,5,20,23,25-32 VEGF, whose expression increases with hypoxia, necrosis or p53 gene inactivation, regulates angiogenesis in high grade gliomas and presents their malignant nature. At the same time, bFGF involved in angiogenesis in gliomas shows synergism with VEGF. ${ }^{19,22,33}$ Angiopoietins regulate angiogenesis in astrocytomas to the greatest extent, so the involvement of VEGF and bFGF appears to be less significant. ${ }^{33}$ In meningiomas, though, VEGF overexpression is observed; however, it is not triggered by hypoxia, as in gliomas, but rather by the concomitant overexpression of platelet-derived growth factor (PDGF) or epidermal growth factor (EGF). ${ }^{7}$ The pro-angiogenic activity of VEGF in GBM is confirmed by the detection of over 50 times higher VEGF mRNA expression in tumor cells than in healthy cerebral tissue. ${ }^{22}$ Gupta et al. assessed the density of vascular network in different cases of glioma relative to their VEGF expression, demonstrating a positive correlation between the 2 factors with the highest values in HGG; this was in line with reports by Berkman et al. and Takano et al. ${ }^{23,24,30}$ Maiuri et al. presented interesting findings, demonstrating that in LGGs that transformed into HGGs, the baseline VEGF expression was higher than in other benign tumors, which may constitute an essential risk factor for malignant transformation. ${ }^{34,35}$ Additionally, Krauze et al. demonstrated a significant elevation of urine VEGF concentration in patients with GBM treated with radiotherapy (RT) for tumor progression (69.5\% of 202 patients). ${ }^{36}$ They suggested that regular measurements of urinary VEGF concentration in patients with GBM can facilitate prediction and may be used for monitoring remission.

There are considerably fewer reports addressing the role of bFGF in brain tumor angiogenesis. The observation by Loilome et al. that blocking the FGF signaling pathway in GBM as a monotherapy slows down tumor growth therefore appears to be particularly important. ${ }^{32}$ The same study also confirms the involvement of bFGF in stimulating tumor growth. As the role of angiogenesis in brain tumor growth is established and indisputable, attempts have been made to use anti-angiogenic agents in cancer treatment. However, these attempts have not yet led to a breakthrough in brain tumor therapy. Additionally, some researchers have reported anti-angiogenic agents as toxic. ${ }^{12,13,17,22,26}$

Bevacizumab - a humanized monoclonal anti-VEGF antibody - was the first anti-angiogenic treatment to be used in high grade gliomas. Numerous trials of this antibody in glioma therapy are being carried out, and although the preliminary data appear to be promising, we still have to wait for the final conclusions. ${ }^{11,13,14,17,22}$ Many authors, for instance Hamerlik et al, have observed that solid tumors respond better to anti-VEGF therapy, including blocking antibodies or tyrosine kinase inhibitors, when it is combined with radiation therapy or administered prior to RT, due to the radiosensitizing effect. ${ }^{27}$ At the same time, along with hopes regarding anti-angiogenic therapy for brain tumors, doubts have arisen that it may paradoxically promote tumor growth, as the induced tumor necrosis with the associated hypoxia are significant triggers of pro-angiogenic factor release. ${ }^{5,7,18,37-39}$ In 2014, an article by a Dutch research team addressing the issue of anti-angiogenic tumor therapy in pediatric brain tumors attempted to determine whether this type of therapy was effective. ${ }^{20}$ It should be noted that most observations regarding angiogenesis in brain tumors are derived from studies in adult populations, whereas the number of studies addressing this issue in children is very limited. The article raised reasonable doubt regarding the enrolment of pediatric patients in clinical studies that involve the administration of anti-angiogenic agents. ${ }^{20}$

Given the unsatisfactory treatment outcomes in brain tumors in children, especially HGG and infiltrative brain stem tumors, any attempt to research new therapeutic approaches or strategies matters. This is the idea the present authors had in mind when choosing to address the issue of angiogenesis in brain tumors in children. Since the findings of this study appear ambiguous, it seems appropriate to continue the research on a larger patient sample. The best option would be to conduct a multicenter study.

\section{Conclusions}

The significant VEGF level elevation in children with malignant tumors suggests its importance in brain tumor oncogenesis. Further studies with larger groups of 
patients should be conducted to determine the significance of the observed elevated VEGF and bFGF levels in the diagnostic process.

\section{References}

1. Carmeliet P. Angiogenesis in health and disease. Nat Med. 2003;9:653-660.

2. Folkman J. Angiogenesis and apoptosis. Semin Cancer Biol. 2003;13:159-167.

3. Mizia-Malarz A, Sobol G, Woś H. Angiogeneza w przewlekłych schorzeniach zapalnych i nowotworowych. Pol Merk Lek. 2008;XXIV:185-189.

4. Domagała W. Molekularne podstawy karcynogenezy i ścieżki sygnałowe niektórych nowotworów ośrodkowego układu nerwowego. Pol Przegl Neur. 2007;3:127-141.

5. Mizia-Malarz A, Sobol G, Woś H. Czynniki proangiogenne: naczyniowo-śródbłonkowy czynnik wzrostu (VEGF) i zasadowy czynnik wzrostu fibroblastów (bFGF) - charakterystyka i funkcje. Przeg Lek. 2008;65:353-357.

6. Mizia-Malarz A, Sobol G, Janowska J, Zahorska-Markiewicz B. Prognostic value of proangiogenic cytokines in children with lymphomas. Pediatr Blood Cancer. 2009;53:1195-1199.

7. Jain RK, di Thomaso E, Duda DG, Loeffler JS, Sorensen AG, Batchelor TT. Angiogenesis in brain tumors. Nat Rev Neurosci. 2007;8:610-622.

8. Kim CY, Kim SK, Phi JK, Lee MM, Kim IA, Kim IH. A prospective study of temozolomide plus thalidomide during and after radiation therapy for pediatric diffuse Pontiac glioma: Preliminary results of Korean Society for Pediatric Neuro-Oncology study. J Neurooncol. 2010;100:193-198.

9. Perek D, Roszkowski M. Nowotwory ośrodkowego układu nerwowego u dzieci. Diagnostyka i leczenie, $2^{\text {nd }}$ ed. Warszawa: Fundacja Neuronet 2006.

10. Bleeker FE, Molenaar RJ, Leenstra S. Recent advances in the molecular understanding of glioblastoma. J Neur Oncol. 2012;108:11-27.

11. Chi AS, Sorensen AG, Jain RK, Batchelor TT. Angiogenesis as a therapeutic target in malignant gliomas. The Oncologist. 2009;14:621-636.

12. Hwang El, Jakacki RI, Fisher MJ, LB, Horn M, Vezina G, Rood BR, Packre RJ. Long term efficacy and toxicity of bevacizumab - based therapy in children with recurrent low grade gliomas. Pediatr Blood Cancer. 2013;60:776-782.

13. Kieran MW, Tuner CD, Rubin JB. A feasibility trial of antiangiogenic (metronomic) chemotherapy in pediatric patients with recurrent or progressive cancer. J Pediatr Hematol Oncol. 2005;27:573-581.

14. Norden AD, Drappatz J, Wen PY. Antiangiogenic therapies for high grade glioma. Nat Rev Neurol. 2009;5:610-620.

15. Peyrl A, Azizi A, Czech T. Tumor stabilization under treatment with imatinib in progressive hypothalamic - chiasmatic glioma. Pediatr Blood Cancer. 2009;52:476-480.

16. Samuel DP, Wen PY, Kieran MW. Antiangiogenic (metronomic) chemotherapy for brain tumors: Current and future perspectives. Expert Opin Investig Drugs. 2009;18:973-983.

17. Thompson EM, Frenkel EP, Neuwelt EA. The paradoxical effect of bevacizumab in the therapy of malignant gliomas. Neurology. 2011;76:87-93.

18. Trevisan E, Bertero L, Bosa C, et al. Antiangiogenic therapy of brain tumors: The role of bevacizumab. Neurol Sci. 2014;35:507-514.

19. Westmark B. Glioblastoma - a moving target. Upsala J Med Sci. 2012;2:251-256.
20. Sie M, den Dunnem WF, Hoving EW, de Bont ES. Anti-angiogenic therapy in pediatric brain tumors: An effective strategy? Critic Rev Oncol Hematol. 2014;89:418-432.

21. Hargrave D, Bartels U, Bouffet E. Diffuse brainstem glioma in children: Critical review of clinical trials. Lancet Oncol. 2006;7:241-248.

22. Wojtukiewicz MZ, Sierko E, Rybałtowski M. Leczenie antyangiogenne chorych na pierwotne nowotwory ośrodkowego układu nerwowego. Onkol Prak Klin. 2009;5:A48-A55.

23. Berkman RA, Merrill MJ, Reinhold WC, et al. Expression of vascular permeability factor/vascular endothelial growth factor gene in central nervous system neoplasms. J Clin Invest. 1993;91:153-159.

24. Gupta K, Radotra BD, Banerjee AK, Nijhawan R. Quantitation of angiogenesis and its correlation with vascular endothelial growth factor expression in astrocytic tumors. Anal Quant Cytol Histol. 2004;2:223-229.

25. Bao S, Wu Q, Sathornsumetee $\mathrm{S}$, et al. Stem cell-like glioma cells promote tumor angiogenesis through vascular endothelial growth factor. Cancer Res. 2006;66:7843-7848.

26. Grossman R, Rudek MA, Brastianos $H$. The impact of bevacizumab on temozolomide concentration in intracranial U87 gliomas. Cancer Chemother Pharmacol. 2012;70:129-139.

27. Hamerlik P, Lathia JD, Rasmussen R, et al. Autocrine VEGF-VEGFR2Neuropilin-1 signaling promotes glioma stem-like cell viability and tumor growth. J Exp Med. 2012;3:507-520.

28. Iwami K, Natsume A, Wakabayashi T. Cytokine networks in glioma. Neurosurg Rev. 2011;34:253-264.

29. Jouanneau E. Angiogenesis and gliomas: Current issues and development of surrogate markers. Neurosurgery. 2008;62:31-50.

30. Takano S, Yoshii Y, Kondo S, Suzuki H, Maruno T, Shirai S, Nose T. Concentration of vascular endothelial growth factor in the serum and tumor tissue of brain tumor patients. Cancer Res. 1996;56: 2185-2190.

31. Arao T, Matsumoto K, Furuta K. Acquired drug resistance to vascular endothelial growth factor receptor 2 thyrosine kinase inhibitor in human vascular endothelial cells. Anticancer Res. 2011;31: 2787-2796.

32. Loilome W, Joshi AD, Piccirillo S, Angelo VL, Galia GL, Riggis GJ. Glioblastoma cell growth is suppressed by disruption of fibroblast growth factor pathway signaling. J Neurooncol. 2009;94:359-366.

33. Kerbel RS. Tumor angiogenesis: Past, present and the near future. Carcinogenesis. 2008;21:401-410.

34. Maiuri F, Del Baso De Caro M, Siciliano A, et al. Expression of growth factors in brain tumors: Correlation with tumor grade, recurrence and survivals. Clin Neuropathol. 2010;9:109-114.

35. Erdamar S, Bagci P, Oz B, Dirican A. Correlation of endothelial nitric oxide synthase and vascular endothelial growth factor expression with malignancy in patients with astrocytic tumors. J Buon. 2006;11:213-216.

36. Krauze AV, Won M, Graves C, et al. Predictive value of tumor recurrence using urinary vascular endothelial factor levels in patients reciving radiation therapy for Glioblastoma Multiforme (GBM). Biomark Res. 2013;1:29, doi:10.1186/2050-7771-1-29, http://www.biomarkerres.org/content/1/1/2.9.

37. Soda Y, Myskiw C, Rommel A, Verma IM. Mechanism of neovascularization and resistant to anti-angiogenic therapies in glioblastoma multiforme. J Mol Med. 2013;91:439-448.

38. Tuner N, Grose R. Fibroblast growth factor signaling: From development to cancer. Nat Rev Cancer. 2010;10:116-129.

39. Beenken A, Mohammadi M. The FGF family: Biology, pathophysiology and therapy. Nat Rev Drug Discov. 2009;8:8235-8253. 